\title{
Whether Sovereignty?: \\ The Failure of Indonesia in Taking Over Flight Information Region from Singapore 2015-2019
}

\author{
Nabyla Humaira*
}

Faculty of Law, Syiah Kuala University, Aceh, Indonesia

\section{Adwani $^{* *}$}

Faculty of Law, Syiah Kuala University, Aceh, Indonesia

\section{Yakub Aiyub Kadir ${ }^{* * *}$}

Faculty of Law, Syiah Kuala University, Aceh, Indonesia

\begin{abstract}
The concept of 'complete and exclusive sovereignty as defined in international and national law remains poses challenges, especially concerning the effort of Indonesia in taking over the Flight Information Region (FIR) from the Singapore context. The management of FIR by Singapore over the Riau Islands of Indonesia was begun during the British colonial period over Malay territory, which partly became a sovereign state of Singapore in 1965. However, under the syndrome of post-colonialism Indonesia has legalized it through the 1995 bilateral agreement between Indonesia and Singapore. On the other hand, since independence, Indonesia has gradually initiated to take over the FIR until the peak time of the 2015 Presidential Instruction which explicitly orders to take over the FIR of Singapore at the latest in the next four years (2015-2019). However, until the end of 2020, there had been no significant progress. This paper critically investigates such failure within the evolving concept of 'sovereignty through the Third World Approach to International Law (TWAL) paradigm in terms of the global justice system. It is proved that the meaning of 'sovereignty in postcolonial states remains a political rhetoric as also known as 'negative sovereignty'. Hence, this paper contributes to clarifying the meaning of sovereignty in the Indonesian context, so that a new awareness arises to increase the national capacity to take over FIR from Singapore, and hopefully, the 'complete and exclusive' meaning of sovereignty can be perceived in near future, for the maximum benefit of people in Indonesia.
\end{abstract}

Keywords: Sovereignty; Indonesia; Singapore; Flight information region; Global justice.

\section{INTRODUCTION}

International and national law are interacte ${ }^{1}$ and have an impact on the concept of sovereignty for postcolonial states. ${ }^{2}$ It is a matter of dignity that has been recognized by the Charter of the United Nations (UN Charter)

\footnotetext{
*Email: nabyla@mhs.unsyiah.ac.id

** Email: adwani@unsyiah.ac.id

*** Email/Corresponding Author: m.yakub.akadir@unsyiah.ac.id

${ }^{1}$ I Wayan Parthiana, Perjanjian Internasional di dalam Hukum Nasional Indonesia

(Bandung: Penerbit Yrama Widya 2019), 1-3.

2 Ibid., 181.
} 
and various international conventions. The concept leads many states to protect their territory, including land water, and air spaces. ${ }^{3}$

When Indonesia gained independence in 1945, in a transitional period, the boundary is not so clear, and Indonesia was not yet a party of the 1944 Chicago Convention, until up to 1950. ${ }^{4}$ However, since 1946 the Realignment of the Boundary Between the Singapore Flight Information Region and the Jakarta Flight Information Region, and the Agreement Between The Government of The Republic of Indonesia and The Government of the Republic of Singapore on Military Training in Areas 1 and 2, which consists of 3 areas: Riau, Tanjung Pinang, and Natuna, was initiated. The region has been one of the busiest flight routes in the Asia and Pacific region. ${ }^{5}$ Equally, the FIR delegation was formed with the approval of member states of the International Civil Aviation Organization (ICAO) ${ }^{6}$ as stated in Article 2.1.1. Annex $11^{7}$ of the 1944 Chicago Convention, that: "... a State may delegate to another State the responsibility for establishing and providing air traffic services in-flight information regions, control areas, or control zones extending over the territories of the former." 8

Based on the Convention, Britain was appointed as the country that manages the FIR, which also covers above of the territorial waters around Natuna as it were part of the high seas since 1982 United Nations Convention on the Law of the Sea (UNCLOS) was not enacted. Unfortunately, Indonesia and Singapore signed a new agreement on FIR with various new provisions held in Singapore on September 21, 1995. 9 This agreement considered to legalise the colonial-based arrangement of FIR over Indonesian space, instead of taking over it.

Since early on, it was deemed that Indonesia has never benefited, even caused many disadvantages, in terms of national defense, economy, and

${ }^{3}$ Nabyla Humaira, "Tinjauan Hukum terhadap Flight Information Region Asing di Wilayah Udara Indonesia (Suatu Kajian terhadap Flight Information Region Singapura)" (Bachelor's Thesis, Syiah Kuala University, 2018), 7.

${ }^{4}$ H.K. Martono and Amad Sudiro, Hukum Udara Nasional Dan Internasional Publik (Public International and National Law), Second Edition, (Jakarta: Raja Grafindo 2016), 254.

5 Ibid., 9 and 56.

${ }^{6}$ International Civil Aviation Organization (ICAO) functions for regulating and developing basic principles of international aviation navigation techniques to increase the growth of international air transportation which ensures safety, and for the growth of international civil aviation throughout the world. Indonesia has become a member of ICAO on 27 May 1950 after submitting to the Chicago Convention 1944 and has ratified the Protocol on The Authentic Six-Language Text of The Convention on International Civil Aviation Chicago 1944 with Presi dential Regulation No. 6 of 2005.

${ }^{7}$ Annex 11 to the Convention on Internatonal Civil Aviation, Fifteenth Edition, July 2018, 33. Through International Civil Aviation Organization (ICAO)

8 Chicago Convention 1944 is an international convention or agreement that regulates international civil aviation. In full, this convention is entitled Convention on International Civil Aviation (1944). This convention is used as a source of law in every international flight activity of countries, and is included in an international agreement which is a law making treaty.

9 This agreement was ratified through Presidential Decree No. 7 of 1996 dated 2 February 1996 concerning "Ratification of the Agreement Between Government of the Republic of Singapore on the Realignment of the Boundary Between the Singapore Flight Information Region and the Jakarta Flight Information Region". Ibid., 55 
politics. Based on a study in 2018, Indonesia has never known the income from the management of the FIR, and suspiciously found illegal actions such as intelligence activities, aerial photography, and train its aviators in the FIR area. If there would be an open conflict it can be used as an air operations strategy which Singapore can take advantage of the superior technology of airpower in the form of speed and suddenness. ${ }^{10}$ Even more, if the Indonesian Government intends to carry out state activities such as rescue operations and military training in FIR areas, the Indonesian Directorate General of Civil Aviation has to notify the Singapore Civil Aviation Agency.

Law No. 1 of 2009 concerning Aviation (hereinafter referred to as the Aviation Law 2009) states that: "The Unitary State of the Republic of Indonesia has full and exclusive sovereignty over the territory of the Republic of Indonesia."11 It is in line with the 1944 Chicago Convention highlighted that: "The contracting States recognize that every State has complete and exclusive sovereignty over the airspace above its territory."12 Additionally, Law No. 3 of 2002 concerning State Defence explains that 'State defense aims to safeguard and protect the sovereignty of the state, the territorial integrity of the Unitary State of the Republic of Indonesia, and the salvation of the nation from all forms of threats'. ${ }^{13}$

These provisions have caused many obstacles both from Indonesian civil aviation as well as the implementation of operations and law enforcement in the areas around Tanjung Pinang and Natuna which are carried out under the Air Traffic Control Singapore (ATC Singapore). The 1995 agreement does not regulate the termination aspect, instead of a review at the end of five years and can be extended by mutual agreement of both parties if it is useful to do so. ${ }^{14}$

However, since independence, Indonesia has gradually initiated to take over the FIR until the peak time of the 2015 Presidential Instruction which explicitly ordering to takeover the FIR of Singapore in the next four years (2015-2019) at the latest. However, until the end of 2020, there had been no significant progress. The prospect of reassignment has faced strong resistance from Singapore, in favour of its national interests in security and income through air navigation charges. ${ }^{15}$

\subsection{Research Problem}

${ }^{10}$ Ibid., 57-58.

${ }^{11}$ Law No. 1 of 2009 concerning Aviation, Art. 5.

12 Convention on International Civil Aviation (1944), Art.1.

13 Law No. 3 of 2002 concerning State Defence, Art. 1(1).

${ }^{14}$ Humaira, op.cit., 58-60.

${ }^{15}$ Ridha Aditya Nugraha, Flight Information Region above Riau and Natuna Islands, The Indonesian Efforts to Regain Control from Singapore, German Journal of Air and Space Law 67, no.2 (2018): 236. 
Indonesia has made a lot of efforts in taking over the management of FIR, so it would be essential to question: (1) Whether the failure of Indone sia in taking over FIR has adversely impacted sovereignty issues, instead of technical one?, and (2) how far sovereignty concept be understood in Singapore-Indonesia FIR context?

\subsection{Method}

This research uses a juridical-normative methodology which conducted by examining legal norms in international conventions and national legislations. ${ }^{16}$ In particular, a critical legal research under the auspice of the Third World Approach to International Law (TWAIL) paradigm, to look at the Western colonial arrangement and its impact on global injustice in postcolonial states has been utilised. This methodology is considered appropriate to examines the concept of sovereignty and its application over the colonial-based agreement of the Indonesia and Singaporean Government on FIR. ${ }^{17}$ Additional sources have also been reached through online interviews with several legal experts from various institutions, such as the Indonesian Centre for Air and Space Law Studies (CASL), and the like.

\subsection{Theoretical Framework}

Sovereignty can be interpreted as the supreme power which is absolute, complete, unanimous, and cannot be divided, and therefore cannot be placed under other powers. However, in the process of further development, there has been a different evolving meaning of sovereignty. ${ }^{18}$

The 1919 Convention Relating to the Regulation of Aerial Navigation, stated that:

"The High Contracting Parties recognise that every Power has complete and exclusive sovereignty over the air space above its territory. For the purpose of the present Convention, the territory of a State shall be understood as including the national territory, both that of the mother country and of the colonies, and the territorial waters adjacent the reto." 19

The article is in line with the Expert opinions, such as H.K. Martono that clearly explained that a sovereign is the highest power (supreme authority) which is free from the power of other countries, free in the broadest sense both inside and outside aspects, but it must still pay

16 Soerjono Soekanto and Sri Mamudji, Penelitian Hukum Normatif, (Jakarta: PT Raja Grafindo Persada, 2012), 12.

${ }^{17}$ Obiora Chinedu Okafor, "Critical Third World Approaches to International Law (TWAIL): The ory, Methodology, or Both?," International Community Law Review 10, no.4 (2008): 371-378. See also Mike McConville and Wing Hong Chui, Research Method for Law, (Edinburg: Edinburg University Press, 2007), 183-186.

18 Suryo Sakti Hadiwijoyo, Pembatasan Negara dalam Dimensi Hukum Internasional (Yogyakarta: Graha Ilmu, 2011), 8.

${ }_{19}$ Convention Relating to the Regulation of Aerial (1919), Art. 1 Navigation, 
attention to international law and social courtesy. ${ }^{20}$ As a sovereign state, it can determine the form of the state, the form of government, the organization of internal and external power, regulating relations with its citizens, the use of the public domain, making basic laws and implementing regulations, establishing international relations with other countries, protecting citizens abroad and within the country, including foreign nationals in their territory, also regulating land, sea and air areas for defense and security, aviation safety and social activities. Eddy Purnama explained that 'state sovereignty is the full power of the state to regulate all the interests of the country to realize the welfare of its people without interference from other countries. ${ }^{21}$

The 1944 Chicago Convention was born based on the economic potential possessed by countries as well as being a reference in international treaties on airspace. Article 1 states: "The contracting States recognize that every State has complete and exclusive sovereignty over the airspace above its territory." This article regulates the sovereignty possessed by participating countries and recognizes the sovereignty of all countries in the airspace above their territory (airspace). According to E. Saefullah Wiradipradja, the universal nature of the article can be seen from the use of the term "every state" to refer to the sovereignty of the parties in air space, which shows that state sovereignty in air space is owned by all countries. Not only countries participating in the convention, but also countries outside the convention. ${ }^{22}$ The concept of state sovereignty in this airspace is a development from the concept of Roman law which reads "cujus est solum, ejus esque ad coelum" which means "Whoever owns a piece of land thus also owns everything on it up to the sky and everything in it ground." 23

Article 25 of the 1945 Constitution of the Republic of Indonesia (Indonesian Constitution), defines State as "the Unitary State of the Republic of Indonesia is an archipelago country, characterized by an archipelago".24 According to Mochtar Kusumaatmadja, the archipelago concept is characterized as the concept of unilateral control of territory by the Indonesian people in breaking the prevailing international maritime law doctrine. ${ }^{25}$ The regulation of sovereignty in national law is important to be reviewed to understand how national law regulates this matter, especially the Indonesian Constitution and laws and operational regulations under it, especially Law No. 43 of 2009 concerning State Territory and the Aviation Law.

20 Martono and Sudiro, op.cit., 64

21 Eddy Purnama, "The Meaning of Indonesia Sovereignty According to the Contitutional Law Experts." Online interview by Nabyla Humaira, via Whatsapp, March 17, 2021.

${ }^{22}$ E. Saefullah Wiradipradja, Pengantar Hukum Udara dan Ruang Angkasa Buku I, (Bandung: PT. Alımni. 20141. 108

23 E. Saefullah Wiradipradia. "Wilavah Udara Negara (state air territorv) Ditiniau Dari Segi Hukum Internasional dan Nasional Indonesia," Indonesian Journal of International Law 6, no.4 (2009): 499.

24 The 1945 Constitution of the Republic of Indonesia, Art. 25.

25 Mochtar Kusumaatmadja, Konsepsi Hukum Negara Nusantara pada Konferensi Hukum Laut 1982 (Bandung: PT. Alumni), 43. 
The 2009 Aviation Law states that: "the Unitary State of the Republic of Indonesia has complete and exclusive sovereignty over the territory of the Republic of Indonesia." The aforementioned provisions clearly state that Indonesia is completely and exclusively sovereign to regulate its airspace. Article 1 paragraph (1) of Law No. 3 of 2002 concerning State Defence explains that State defense aims to safeguard and protect the sovereignty of the country, the territorial integrity of the Unitary State of the Republic of Indonesia, and the safety of the nation from all forms of threats. ${ }^{26}$

Referring to the above provisions various issues of sovereignty arise since the Indonesia and Singapore FIR bilateral agreement, in terms of security and defense, economy, and politics.

\section{RESULT AND ANALYSIS}

\subsection{Sovereignty and Colonial-Based Agreement}

The state as the firm international legal subject has been emerged with its sovereignty, that a state can establish and carry out legal relations with fellow countries in all fields of international relations, one of which is to make and/or become a participant in an international agreement. ${ }^{27}$

Indonesia has participated in international and regional efforts to maintain security and peace in various sectors. Particularly in the management of airspace over the Riau Islands, when Indonesia signed a bilateral agreement with the Republic of Singapore which was ratified by Presidential Decree No. 7 of 1996 and the Agreement on Military Training in Areas 1 and 2 which was ratified by Presidential Decree No. 8 of 1996. This agreement was originally established with the approval of ICAO member countries in 1946 based on Article 2.1.1. Annex 11 of the 1944 Chicago Convention. ${ }^{28}$

Under colonial context, Britain was appointed as the country that manages the FIR where at that time Singapore was still under a British Commonwealth territory. Equally, in 1946 the territorial waters around Natuna were part of the high seas and were not included yet in the territory of Indonesia. Therefore, Indonesia was not seen as having an interest in the area, and when Indonesia gained independence in 1945, Indonesia was still in a transitional period and its boundaries with neighboring countries were not clear. Even more, Indonesia was not yet a part of the 1944 Chicago Convention, until 1950. ${ }^{29}$

In 1965 Singapore was officially independent, but the FIR agreement between the Republic of Indonesia and Singapore regarding the management of airspace was continuing. Essentially, it should be

${ }^{26}$ Law No. 3 of 2002 concerning State Defence, Art 1 (1).

27 Parthiana, op.cit., 114

${ }_{28}$ M. Y. Aiyub Kadir, "Application of the Law of Self-Determination in a Postcolonial Context: A Guideline," Journal of East Asia and International Law 9, no.1 (2016): 7. Also M.Y. Aiyub Kadir, "Revisiting Self-Determination Conflicts in Indonesia: An International Law Perspective," Indonesia Law Review 5, no.2 (2015): 123.

${ }_{29}$ Martono and Sudiro, op.cit., 254. See also Humaira, op.cit., 6-7. 
automatically ended under the succession principle of colonial regimes. Particularly Indonesia has taken over its sovereignty from the Netherland, so the Netherlands has a responsibility to return the FIR from Britain to newly independent states (Indonesia). Such a situation should be taken into account by the Indonesian government to reconsider the meaning of sovereignty in the taking over process of the FIR from Singapore.

In July 1992 Indonesia has intensified its efforts to take over the FIR. Indonesia officially conveyed this at the Regional Air Navigation (RAN) Meeting in Bangkok in May 1993, but at the RAN-Meeting it was decided that this issue would be resolved bilaterally between Indonesia and Singapore, the results of which must be reported to ICAO. Continuing the decision of the ICAO board, Indonesia and Singapore sent delegates reciprocally to discuss the FIR takeover. Singapore was still questioned the legal basis which determined the location of the outer starting point of Indonesia and did not agree with Law No. 17 of 1985 which was ratified by Indonesia. At that time it was clear that UNCLOS had been enacted and was in effect in the territory of Indonesia.

The failure of Indonesia at that time was because it had not yet established a starting legal point and Singapore brought a map of Indonesia based on Government Regulation in Lieu of Law No.4 of 1960 concerning Indonesian Waters which was just published at the United Nations in 1986. This was very different from the sovereign territory based on UNCLOS 1982. Nevertheless, Indonesia was not been able to provide a good argument so that the takeover attempt is still unsuccessful. ${ }^{30}$

Since the transfer of sovereignty by the Kingdom of the Netherlands in 1949 through the Round Table Conference and various developments in its sovereignty, so related to international relations, both multilateral and bilateral agreements must be reviewed with the countries concerned so that their enforcement in accordance with the sovereignty of the postcolonial states. In particular, the bilateral agreement that was promised by Indonesia and Singapore regarding the management of airspace over the Riau Islands was no longer benefits Indonesia and at the same time directly or indirectly, this bilateral agreement has disturbed the sovereignty of the Republic of Indonesia, as it was colonial based agreement. ${ }^{31}$

Violation of airspace sovereignty can be seen from several aspects, one of them is from the economic sector where Indonesia has never received the annual income report from FIR management by Singapore. Meanwhile, the management of airspace will be a threat in which Singapore will very easily carry out illegal activities such as intelligence, aerial photography, and even utilizing the airspace as a Singapore military training ground. While Indonesia has to report every flight that carries the President or other important officials which are secret flights.

On the other hand, Singapore has never reported anything to the Indonesian authority. Indonesia must request permission every time it will

\footnotetext{
30 Ibid., 271-272

${ }^{31}$ See Kadir, Revisiting... op.cit., 23.
} 
carry out law enforcement operations by the National Air Defense Command or the Indonesian Navy in this territory. These operations are often prohibited on the grounds of disturbing the security of Singapore's territory. ${ }^{32}$ Based on these various issues, the FIR bilateral agreement between Indonesia and Singapore does not deserve to be continued and is against the meaning of the sovereignty of Indonesia.

\subsection{Flight Information Region and Negative Sovereignty}

Complete and exclusive sovereignty of the state in space is different from the territorial sea. Due to its nature, the right of innocent passage is not known in the air for foreign parties, while in the territorial sea it is limited by the rights of other countries to exercise the right of innocent passage. ${ }^{33}$ The airspace of a country is completely closed to foreign aircraft, both civilian and military. Only with prior permission from the underworld, either through bilateral or multilateral agreements, a country's airspace can be traversed by foreign aircraft. The state then regulates in its national law how to strengthen state sovereignty over the air space as a natural resource that can be utilized for national defense and the prosperity of the people. ${ }^{34}$

Singapore's FIR, which has been managing the airspace over Indonesia's Riau Islands, has contributed a lot of harm to Indonesia, especially in terms of national defense and security. For example, in the case of civil aviation, Indone sia must ask for permission every time it passes through the Riau Islands region. Another example is Singapore prohibiting the Indonesian Air Force to have military training in the area on the grounds of threatening the security of Singapore's territory. ${ }^{35}$ The prohibition and various violations cannot be accepted by Indonesia because the agreement only provides the managerial rights to Singapore, not a flight restriction zone or even the handover of Indonesian territory. Indonesia should have the right to conduct civilian flights or even military training over the area and only need to report for the safety flight in accordance with applicable rules without violating various privacy and safety.

In reality, Indonesia has suffered a lot of disadvantages so that since July 1992 Indonesia has intensified its efforts to take over this FIR, which was officially conveyed at the Regional Air Navigation (RAN) Meeting in Bangkok in May 1993. However, the meeting decided that this issue would be resolved bilaterally between Indonesia and Singapore, and the results of which must be reported to the Civil Aviation Organization in Bangkok. ${ }^{36}$

${ }^{32}$ Humaira, op.cit., 7-8, 55.

33 E. Saefullah Wiradipradja, Pennantar Hukum IJdara ... on cit 98

${ }^{34}$ E. Saefullah Wiradipradia. "The Indonesian Sovereientv Over Air Space and its Urgencv for National Economic Development." Paper presented in 50 Years of International Conference on Air and Space Law Studies, Padjadjaran University, Bandung, 5-6 November (2014)

\footnotetext{
35 Humaira, op.cit., 56

36 Martono dan Sudiro. op. cit., 270.
} 
Since then, Indonesia has prepared all tools needed to serve FIRs on Natuna Island to ensure the safety of national and international flights. ${ }^{37}$ This takeover effort is also mandated in the Aviation Law 2009 which states that within 15 years from the enactment of the regulation, all airspace managed by foreigners must have been returned to Indonesia. The mandate of the law was strengthened again through a Presidential Instruction in September 2015. Minister of Transportation Ignatius Jonan in a press conference at the Presidential Office acknowledged this instruction that within 3-4 years to prepare better equipment and personnel so that the FIR Singapore will soon be taken over and managed by Indonesia by 2019 at the latest. ${ }^{38}$ In fact, however, until December 2020 there had been no significant progress perceived.

Airspace services over the Republic of Indonesia air that has been delegated by Indonesia to Singapore based on bilateral agreements, particularly the FIR over Natuna Island, within 15 years from the Aviation Law 2009 was enacted. Based on the review of time frame to determine the FIR which is every 10 years at the representative offices of the International Civil Aviation Organization in Bangkok by Asia-Pacific countries. So it should have been done in 2013, but those efforts have no results. This case has provided a new perspective on the theory of "delegation of authority" as stipulated within the Chicago Convention, which has evolved into the effective "delegation of sovereignty" when fundamental national interests are involved.

The civil aviation world is really dynamic considering its dependency on various rapidly evolving aspects, from technological innovation to world political changes. There has been a lack of transparency since the Indonesian Directorate General of Civil Aviation has no full access to the Civil Aviation Authority of Singapore's data. ${ }^{39}$ However, the commercial calculations seem to still be unfavourable for Indonesia. It is reported that in 2015 each flight on a Sector A route is charged six U.S. dollars, while only 50 cents or around $8 \%$ is allocated to Indone sia $^{40}$ Additional problems also arise since Indonesian aircraft are often warned not to fly some areas which are announced as being used for Singaporean Air Force training. ${ }^{41}$

37 Ibid., 271.

38 Mega Putra Ratya, "Instruksi Jokowi: Segera Ambil Alih Ruang Udara RI yang Dikuasai Singapura," Detik.Com, 8 September 2015, https://news.detik.com/berita/d3013345/instruksi-jokowi-segera-ambil-alih-ruang-udara-ri-yang-dikuasai-singapura

39 Evi Zuraida, "Tinjauan Yuridis Upaya Pengambilalihan Pelayanan Navigasi Penerbangan pada Flight In- formation Region (FIR) Singapura di atas Wilayah Udara Indonesia Berdasarkan Perjanjian antara Indonesia Singapura Tahun 1995" (Master Thesis, Faculty of Law, Universitas Indonesia, 2012), 115.

Ruang

${ }^{40}$ Anggi Kusumadewi et.al. "Luhut: Singapura-Malaysia Dukung RI Kendalikan

$\begin{array}{llll}\text { Ruang } & & & \text { Udara”, } \\ \text { CNN Indonesia, } & 5 & \text { October } & \text { 2015, }\end{array}$

Http://www.cnnindonesia.com/nasional/20151004171137-20-82698/luhutsingapura-malay-sia-dukung-ri-kendalikan-ruang-udara/ and Anggi Kusumade wi and Abraham Utama, "Perang Udara Indonesia-Singapura," CNN Indonesia, 5 October 2015, http://www.cnnindonesia.com/nasional/20151004164 716-20-82695/perangudara-indonesia-singapura/

${ }^{41}$ Chappv Hakim. "Pertahanan Indonesia Angkatan Perang Kepulauan." Jakarta: Red and White Publishing, 2011, 112-113. 
The Indonesian Air Force feels threatened by the current situation they cannot conduct their missions freely within their own airspace, especially objectionable as they are performing state (military) and not civil and commercial flights. ${ }^{42}$ Such inability of Indonesia to date to take over its FIR from Singapore, considered to be called 'negative sovereignty' as mostly the issue of postcolonial states. ${ }^{43}$

The complete sovereignty of the Republic of Indonesia seems capable of conducting bilateral and even multilateral agreements, at the same time, Indonesia has not been able to cancel agreements that are detrimental from various points of view. The study of the airspace over the Riau Islands which is managed by Singapore is very interesting when viewed from negative sovereignty and positive sovereignty perspective. Positive state sovereignty has a dark side to the countries with negative sovereignty. Positive sovereignty in a country can result in the country becoming a colonizer or an exploiter. ${ }^{44}$ If this continues, the countries with negative sovereignty are in danger of being eroded and violated. 45

It can be concluded that state sovereignty is just a word that has various meanings by referring to the conceptual scheme used by a state. So, it can be said that the country with sovereignty was able to power into or out of the area so that it is rightly powerful and empirically sovereign.

The ratification of certain international treaties essentially must be ratified by legislation so that the hierarchy and validity of the se international treaties are the same as other national laws, but if an international treaty is ratified by a presidential decree or a presidential regulation, so it is under other Indonesian national laws. Thus, international treaties which are under national law, and their enforcement must prioritize national regulations. This is in line with the existence of a bilateral agreement between Indonesia and Singapore regarding the management of airspace which is ratified by a presidential decree, while the national regulations covering national defense and security as well as state sovereignty are in the form of laws, so the enforcement of national laws should take precedence over on the validity of the bilateral agreement between Indonesia and Singapore.

Complete and exclusive national sovereignty will remain a term in the rule of law when the ruler of a country is capable and fully empowered in making a decision related to the security and defense of his country so that the ruler or government of a country can be said to be competent in making

42 The Indonesia-Singapore Agreement of 1995, Art. 10.

${ }^{43}$ Robert Jackson, Quasi-states: Sovereignty, International Relations, and the Third World, Cambridge: Cambridge University Press 1990. Ed. Surya P. Subedi, Book Review: Quasi-states: Sovereignty, International Relations, and the Third World Asian Yearbook of International Law.

${ }^{44}$ Zezen Mutaqin, 'Negative Sovereignty and Positive Sovereignty (Why the Great Powers Invade Outlaw States)", Canterbury Amicus Curiae Law Journal University of California 1, No. 4 (2017): 59.

45 Martti Koskenniemi, "What Use for Sovereignty Today?," Asian Journal Of Internasional Law 1, no.1 (2011): 69. 
a good decision, nationally and internationally. This is in line with Polidano's writings in his journal, ${ }^{46}$ which stated that:

"The idea of state capacity is a useful way of conceptualizing and measuring the ability of governments to implement policy. Without which such a capacity the idea of sovereignty becomes rather meaningless. State capacity here is understood as 'its freedom to make decisions, its ability to make informed decisions, and its ability to have those decisions implemented."

Thus, the sovereign is dependent on a great influence on how the policy issued by the government and how its application in the governance will affect the authority of a country in the international relation. So in this case the internal factors of a country will be very influential for the creation of complete and exclusive sovereignty.

Jackson argues that Sovereignty juridically refers to the recognition of other sovereign states while empirically, sovereignty refers to the ability of a state to control and manage its territory. ${ }^{47}$ Based on Robert's opinion and looking at the reality that Indonesia is currently experiencing, it is seen that this country was only juridically sovereign, but empirically more related to the management of airspace over the Riau Islands, Indonesia cannot be said to be empirically sovereign. Besides, the Presidential Instruction in 2015 strengthens the implementation of the mandate in Law No. 1 of 2009 on Aviation. Article 458 describes the takeover of FIR Management no later than 15 years from the enactment of the Law. In 2019 the mandate should be realized, but in fact, until December 2020 the takeover is still rhetoric, it is in this sense sovereignty need to be questioned.

\subsection{Primate Monism of National Law}

According to the doctrine of monism under the primate of national law, international law is sourced from national law. State practice as a basis for the development of customary international law signified the concept that so national law has a higher position than international law, if there is a conflict between them, national law takes precedence. 48 This understanding sees that the unity of national law and international law is essentially international law was derived from national law. The reasons put forward are as follows:49

46 Charles Polidano, 'Measuring public sector capacity', World Development, 28 (5): 805-822, (2000): 809.

47 Jackson, loc.cit.

48 Se friani, Hukum Internasional: Suatu Penaantar (Jakarta: Raia Grafindo Persada 20111. 86. See also Hasim. Hasanııddin. "Hıbıngan Hııkım Internasional Dan Hılkım Nasional. Perspektif Teori Monosime Dan Teori Dualisme." Jurnal Perbandingan Mahzab 1 (2019): 166-179. https://doi.org/10.24252/mh.v1i2.10623

49 Ibid., 86-87. 
1. the absence of an organization above the states that regulate the life of those countries;

2. the basis of international law to regulate relations between countries lies in the authority of the state to enter into international agreements that derive from the authority granted by the constitution of each country.

Thus, the bilateral agreement agreed by Indonesia and Singapore regarding the management of airspace over the Riau Islands must prioritize the national legal rules of the Republic of Indonesia, especially relating to sovereignty which will later affect the security and defense of the Republic of Indonesia. The practice is implemented through Article 10 of Law No. 24 of 2000 concerning International Treaties that requests ratification of an international treaty that covers inter alia changes in the territory or the determination of the territorial borders of the Republic of Indonesia as well as sovereignty and sovereign rights issues, through a national law that jointly agreed by the House of Representatives and the President.

However, the arrangements regarding the ratification of international treaties were previously regulated in Presidential Letter No. 2826/HK/1960 but then because in practice there were many irregularities, Law No. 24 of 2000 concerning International Treaties (hereinafter referred to as UUPI) was established. The transitional rule of the UUPI also says nothing about the validity of previous agreements. It only mentions the ratification of international agreements which are still in the process of being finalized by these provisions. 50 Hence, the absence of provisions that confirm the validity of the agreements that were made before, has made the Bilateral Agreement is questionable. 51

Relating to the existence of the UUPI which states that agreements on sovereignty rights must be ratified by enactment, however, it does not apply retroactively, considering what has been done previously as legal action on behalf of the state and it is valid as long as no repeal. However, it is different from the bilateral agreement that has harmed one of the parties, so if the review of the bilateral agreement does not provide a favorable solution, withdrawal or even revocation is the most reasonable solution carried out by the government of the Republic of Indonesia, the agreement should be questioned.

With regards to internal law regarding competence to conclude treaties, the Vienna Convention on the Law of Treaties 1969 (VCLT) states:

"Provisions of internal law regarding competence to conclude treaties:... a State may not invoke the fact that its consent to be bound by a treaty has been expressed in violation of a provision of its internal law regarding competence to conclude treaties as invalidating its consent unless that violation was manifest and concerned a rule of

${ }^{50}$ Law No. 24 of 2000 concerning International Treaties, Art. 21.

${ }^{51}$ Maulida Hadry Sa'adillah, the author was interviewed her about the validity of bilateral agreements according to international law, online interview via Instagram, at 07.39 WIB and 19.39 in New York, 2021. 
its internal law of fundamental importance. (2) A violation is manifest if it would be objectively evident to any State conducting itself in the matter following normal practice and good faith." 52

The provisions above can be understood that the party who promised something through an international agreement, in this case, is a bilateral agreement between Indonesia and Singapore about the management of airspace over the Riau Islands, which is the sovereign territory of the Republic of Indonesia, has been questioned due to violating of national law. ${ }^{53}$ VCLT also affirms the termination and withdrawal of international treaties that the parties have the right to withdraw from an international treaty on terms agreed by the parties. ${ }^{54}$

It stipulates that each country has complete and exclusive sovereignty over the territory of its country whether on land, sea, or air. Each country has the right to regulate every matter related to the interests of its territory. Indonesian national law through various applicable laws and regulations reinforces the sovereignty of a country that is complete and exclusive. Thus, the bilateral agreement that was agreed between Indonesia and Singapore, which has now tarnished the meaning of complete and exclusive sovereignty for Indonesia, has to take over as soon as possible.

\section{CONCLUSION}

The meaning of complete and exclusive sovereignty as associated with an independent post-colonial state has been contested as there have been different understandings arise in Indonesia's delegated power to control FIR to Singapore, whether it is merely a technical or sovereignty. The control was initiated in the colonial era when the British occupied the Malay territory, which then partly become a new independent state of Singapore in 1965. Hence the historical context of FIR should be taken into account as the meaning of sovereignty has to invalidate the colonial-based related agreements. It is found that despite it is a technical issue of controlling certain spaces over the territory of Indonesia, signaled to erosion of sovereignty when Indonesia remains unable to take over it up to the end of 2020. The very strong order of president Jokowi through his 2015 instruction has not been effectively proven. Despite Indonesia has initiated various political efforts but has been considered failed.

Indonesia has complete and exclusive sovereignty when it legalised the previous colonial-based agreement that Indonesia and Singapore agreed to delegate Singapore on the management of airspace over the Riau Islands. However, in practice, it has proved that Indonesia has faced many disadvantages in terms of economic loss and defense and security.

52 Vienna Convention on the Law of Treaties 1969, Art. (1).

53 Damos Dumoli Agusman, Hukum Perjanjian Internasional (Kajian Teori dan Prkatik Indonesia), Second Edition, PT Refika Aditama, Bandung, 2014, p. 96 Also see Sri Setianingsih and Ida Kurnia, Hukum perjanjian Intenasional (Jakarta: Sinar Grafika, Jakarta 2019), 91.

54 Vienna Convention on the Law of Treaties, Art. 54. 
Ironically, Indonesia has not been able to take over the FIR from Singapore, even under the 2015 Presidential Instruction from 2015 to 2019 . It is proven that the meaning of sovereignty which is 'complete and exclusive' becomes rhetoric only when Indonesia can make an agreement but when the agreement causes losses or even threatens Indonesia's economy and security, Indonesia has not been able to cancel it. Such a situation should be taken into account by the Indonesian government to reconsider the meaning of sovereignty and its capacity to take over FIR from Singapore.

\section{BIBLIOGRAPHY}

\section{Book}

Dumoli Agusman, Damos. Hukum Perjanjian Internasional (Kajian Teori dan Praktik Indonesia). Second Edition. Bandung: PT Refika Aditama, 2014.

Hakim, Chappy. "Pertahanan Indonesia Angkatan Perang Kepulauan." Jakarta: Red and White Publishing, 2011.

Jackson, Robert. Quasi-states: Sovereignty, International Relations, and the Third World. Cambridge: Cambridge University Press 1990. Edited by Surya P. Subedi, Asian Yearbook of International Law.

Kusumaatmadja, Mochtar. Konsepsi Hukum Negara Nusantara pada Konferensi Hukum Laut 1982. Bandung: PT. Alumni, 2004.

Martono and Amad Sudiro. Hukum Udara Nasional Dan Internasional Publik (Public International and National Law), Second Edition, Jakarta: Raja Grafindo, 2016.

McConville, Mike, and Wing Hong Chui, Research Methode for Law, Edinburg: Edinburg University Press, 2007.

Parthiana, I Wayan. Perjanjian Internasional di dalam Hukum Nasional Indonesia, Bandung: Yrama Widya, 2019.

Sakti Hadiwijoyo, Suryo. Pembatasan Negara dalam Dimensi Hukum Internasional, Yogyakarta: Graha Ilmu, 2011.

Sefriani, Hukum Internasional: Suatu Pengantar, Jakarta: Raja Grafindo Persada, 2011.

Setianingsih, Sri and Ida Kurnia. Hukum perjanjian Intenasional, Jakarta: Sinar Grafika, 2019.

Wiradipradja, E Saefullah. Pengantar Hukum Udara dan Ruang Angkasa (Book I), Bandung: PT. Alumni, 2014.

\section{Journal Article}

Aiyub Kadir, MY. Application of the Law of Self-Determination in a Postcolonial Context: A Guideline, Journal of East Asia and International Law, Vol. 9 (1) 2016.

Aiyub Kadir, MY. Revisiting Self-Determination Conflicts in Indonesia: An International Law Perspective, Indonesia Law review, Vol 5 (2) 2015: 123-139. http: / /dx.doi.org/10.15742/ilrev.v5n2.116

Koskenniemi, Martti. "What use for sovereignty today?." Asian Journal of International Law 1, no. 1 (2011): 61-70. https://doi.org/10.1017/S2044251310000044 
Mutaqin, Zezen. "Negative Sovereignty and Positive Sovereignty (Why the Great Powers Invade Outlaw States)," Canterbury Amicus Curiae Law Jurnal University of California 1, no. 4 (2017): 44-61.

Nugraha, Ridha Aditya. "Flight Information Region above Riau and Natuna Islands: The Indonesian Efforts to Regain Control from Singapore." German Journal of Air and Space Law 67, no.2 (2018): 236-253.

Ridha Aditya Nugraha, Flight Information Region above Riau and Natuna Islands, The Indonesian Efforts to Regain Control from Singapore,.

Okafor, Obiora Chinedu. "Critical Third World approaches to international law (TWAIL): theory, methodology, or both?" International Community Law Review 10, no. 4 (2008): 371-378. https: / / doi.org/10.1163/187197308X366614

Polidano, Charles. "Measuring public sector capacity." World Development 28, no. 5 (2000): https:/ / doi.org/10.1016/S0305-750X(99)00158-8

Wiradipradja, E. Saefullah. "The Indonesian Sovereignty Over Air Space and its Urgency for National Economic Development." Paper presented in 50 Years of International Conference on Air and Space Law Studies, Padiadiaran University, Bandung, 5-6 November (2014)

Wiradipradja, E. Saefullah. "Wilayah Udara Negara (state air territory) Ditinjau Dari Segi Hukum Internasional dan Nasional Indonesia." Indonesian Journal of International Law 6, no.4 (2009): 495-503. http://dx.doi.org/10.17304/ijil.vol6.4.211

\section{Thesis}

Humaira, Nabyla. "Tinjauan Hukum terhadap Flight Information Region Asing di Wilayah Udara Indonesia (Suatu Kajian terhadap Flight Information Region Singapura)." Bachelor's Thesis, University of Syiah Kuala, 2018.

Zuraida, Evi. "Tinjauan Yuridis Upaya Pengambilalihan Pelayanan Navigasi Penerbangan pada Flight In- formation Region (FIR) Singapura di atas Wilayah Udara Indonesia Berdasarkan Perjanjian antara Indonesia Singapura Tahun 1995." Master Thesis, Faculty of Law Universitas Indonesia, 2012.

\section{Legal Documents}

Indonesia. The 1945 Constitution of the Republic of Indonesia.

The Law No. 1 of 2009 concerning Aviation.

The Law No. 43 of 2008 concerning State Territory.

The Law No. 3 of 2002 concerning State Defense.

The Law No. 24 of 2000 concerning International Treaties.

Government Regulation in Lieu of Law No.4 of 1960 concerning Indonesian Waters.

Convention on International Civil Aviation, 1944.

Vienna Convention on the Law of Treaties, 1969.

Convention Relating to the Regulation of Aerial Navigation, 1969. 
Agreement Between Government of the Republic of Singapore on the Realignment of the Boundary Between the Singapore Flight Information Region and the Jakarta Flight Information Region, 1955.

Agreement Between the Government of the Republic of Indonesia and the Government of the Republic of Singapore on Military Training in Areas 1 and 2, 1966.

\section{Interviews}

Sa'adillah, Maulida Hadry. "The Validity of Bilateral Agreements According to International Law." Interview by Nabyla Humaira via Instagram, February 22, 2021 at 07.39 AM Western Indonesia Time (19.39 PM) in New York.

Purnama, Eddy. "The Meaning of Indonesia Sovereignty According to the Contitutional Law Experts." Interview by Nabyla Humaira via Whatsapp, March 17, 2021.

\section{Website Content}

Anggi Kusumadewi and Abraham Utama, "Perang Udara IndonesiaSingapura," CNN Indonesia, 5 October 2015, http://www.cnnindonesia.com/nasional/20151004164 716-2082695/perang-udara-indonesia-singapura/

Anggi Kusumadewi et.al. "Luhut: Singapura-Malaysia Dukung RI Kendalikan Ruang Udara”, CNN Indonesia, 5 October 2015, Http: / /www.cnnindonesia.com/nasional/20151004171137-20$82698 /$ luhut-singapura-malay-sia-dukung-ri-kendalikan-ruangudara/

International Civil Aviation Organization (ICAO), https://www.unitingaviation.com/publications/Annex-11/\#page =33

$\begin{array}{ccc}\text { International Civil Aviation } & \text { Organization } & \text { (ICAO), } \\ \text { https://www.icao.int/aboutICAO/defaultpage } & \end{array}$
https://www.icao.int/aboutICAO/defaultpage

$\begin{array}{llll}\text { International Civil Aviation } & \text { Organization } & \text { (ICAO), }\end{array}$
https://www.icao.int/publications/pages/doc7300as px

Ratya, Mega Putra, "Instruksi Jokowi: Segera Ambil Alih Ruang Udara RI yang Dikuasai Singapura," Detik.Com, 8 September 2015, https://news.detik.com/berita/d-3013345/instruksi-jokowi-segeraambil-alih-ruang-udara-ri-yang-dikuasai-singapura 